HELMINTHOLOGIA, 54, 3: 199 - 210, 2017

\title{
Segregated settlements present an increased risk for the parasite infections spread in Northeastern Slovakia
}

\author{
J. PIPIKOVÁ1, I. PAPAJOVÁ1* J. ŠOLTYS', I. SCHUSTEROVÁ2, D. KOČIŠOVÁ2 ${ }^{2}$ A. TOHÁTHYOVÁ
}

${ }^{1}$ Institute of Parasitology of the Slovak Academy of Sciences, Košice, Slovak Republic, *E-mail: papaj@saske.sk; ${ }^{2}$ Department of Paediatrics and Adolescent Medicine, Faculty of Medicine, Pavol Jozef Šafárik University, Košice, Slovak Republic

\section{Article info}

Received March 14, 2017 Accepted June 7, 2017

\begin{abstract}
Summary
The occurrence of parasitic infections among the children, dogs and its association with soil contamination in two villages with different hygiene level standards were analysed. Infections were present in both examined localities, but in the village with higher living standard, a better personal and communal hygiene level and better dogs care a lower occurrence of parasitic germs in soil was detected. High prevalence of protozoa and helminths was observed not only within canine population but also in children throughout the year in the village with lower hygiene and socio-economic standard. We have identified up to 12 taxa of parasites in 127 collected dogs' excrements and mean prevalence was $71.65 \%$. The most frequent were eggs of family Ancylostomatidae and Ascaris spp., followed by Toxocara canis, Toxascaris leonina, Giardia duodenalis cysts, Isospora spp. oocysts, eggs of Capillaria aerophila, Trichuris vulpis, Taenia type eggs, Dipylidium caninum, oocysts of Sarcocystis spp. and larvae of Angiostrongylus vasorum. The soil samples collected near dwellings were highly contaminated. Two thirds of samples contained eggs for the most part of family Ancylostomatidae as well as genera Ascaris and Toxocara. Among the kids population helminth ova were present in $53.17 \%$ of stool samples, where the eggs of Ascaris lumbricoides, Trichuris trichiura, Enterobius vermicularis, Hymenolepis diminuta and cysts of $G$. duodenalis were the most frequent. In contrast, parasitic diseases were not seen in children population living in the locality with common hygiene standard.

Keywords: protozoa infection; helminth infection; soil; dogs; children; Northeastern Slovakia
\end{abstract}

\section{Introduction}

Parasitic infections present still a serious problem of the 21 st century. The WHO Secretariat (2012), Røttingen et al. (2013) and von Philipsborn et al. (2015) classified diseases caused by helminths, roundworms, hookworms, whipworms and tapeworms as type III diseases. It means that above mentioned diseases are noticeably linked with poverty level and socio-economic status of its population. Elyana et al. (2016) reported that intestinal parasitic infections are major public health problem. Particularly in danger are the children living in poor or rural neighbourhoods. Globally, about
1.5 billion people are infected with at least one intestinal parasitic species (Pulan et al., 2014; Hotez et al., 2014). Pulan et al. (2014) reported that in 2010 about 438.9 million people were infected with hookworms. Additionally, 819.0 million Ascaris lumbricoides and 464.6 million Trichuris trichiura infections were identified.

Among of a many parasitic infections, we should principally mention those which are transmitted through the soil or water. They are represented by endoparasites such as Giardia duodenalis, Cryptosporidium spp., Trichuris spp., Ascaris spp., Ancylostoma spp., Toxocara spp., Echinococcus spp., and Toxascaris spp. (Bajer, 2008; Traversa et al., 2014). For diseases caused by endopara-

\footnotetext{
* - corresponding author
} 
sites the most likely route of human infection is fecal-oral transmission followed by the contact with infected humans and animals (wild, stray, domestic), with contaminated food, soil, water, or environment. The main source of the infection is environment contaminated with feces from infected animals living in close vicinity with the man (Despomier, 2003; Szabová et al., 2007; Macpherson, 2013; Ondriska et al., 2013). Parasitic infections are very often transmitted at places with high population density, poor hygiene conditions and low socioeconomic status of community (Adeoye, et al., 2007; Rudohradská et al., 2012; Papajová et al., 2014).

The prevalence of intestinal parasitic diseases in Slovakia is due to its geographical location and good hygiene conditions quite low. However, it may be easily transmitted by socially disadvantaged people living in a low hygiene conditions. Primarily these diseases occur in the population of marginalised communities, which are distinct by complete social exclusion, due to a various factors. In Slovakia, according to the performed research and governmentally released strategy papers the groups put most at risk are the Roma people. This is in Slovakia a very specific problem (Madarasová Gecková et al., 2014). According to the Atlas of Roma communities (Mušinka et al., 2014) there are 803 Roma settlements in Slovakia territory. It is home of more than 215000 people living inside the villages (30.7\%), at the outskirts of the villages (40.4\%) or in segregated settlements (16.6\%). Most of the Roma population lives with the major population (46.5\%) (Filadelfiová et al., 2007; Mušinka et al., 2014). Roma ethnic group inhabit shacks and houses in the villages, apartments with reduced living standards and apartments found on abandoned houses in urban areas (Dubayová, 2001). In the cities, we see urban areas which are exclusively inhabited by Roma people commonly called - Roma ghettos (Mušinka, 2002).

This study focuses on the analysis of the potential health risks caused by parasites in rural locations of Slovakia. The aim of the study was to monitor the occurrence of intestinal parasites in dogs in two Northeastern Slovakian localities with different hygiene standards. The soil contamination near dwellings was evaluated for the period of one year. A coprological diagnostics of intestinal parasites in the children population was also performed.

\section{Material and Methods}

\section{Characterization of the studied localities}

This study was performed in two neighbouring villages in Prešov County (Northeastern Slovakia) that wished to remain anonymous and are further specified as "village A" (about 500 inhabitants) and "village B" (about 510 inhabitants). Both these locations are rural, but differ by hygiene standards, levels of sanitary conditions and socio-economic status of dog owners. The village $A$ is inhabited predominantly by Roma minority group (more than $95 \%$ ) and characterized by a low level of environmental hygiene. Electricity is available for public lighting and to some houses. Clean water supply and sewage systems are not available. Water for the residents is available only through water wells. There are 40 registered dogs which are either tied by chain to the kennel, or moving freely around settlements. They are usually fed on leftovers and households garbage. No data about unregistered animals were available. The neighbouring village $B$ is represented by a higher hygiene and living standards where the gas, electricity, municipal water supply and municipal sewerage are available. Slovak majority population lives in village B where 57 dogs and 10 cats are registered. Dogs are usually kept in the yard and fed by commercially manufactured dry dog food from various manufacturers. Both villages in this study were visited once a month and inspected for the presence of parasites in feces and soil samples.

\section{Coprological examination of excrements}

Totally 199 dog fecal samples were collected and examined for the presence of parasite developmental stages. Dog feces have been collected from around the dwellings, public places or taken directly by the owners from backyards. After collection, fecal samples were stored without any conservation at $4{ }^{\circ} \mathrm{C}$ and transferred to the laboratory at the Institute of Parasitology SAS in Košice for parasitological examination which was performed within $24-48 \mathrm{~h}$. Flotation method with the sucrose flotation solution (specific gravity of 1.27) was used for coprological examination where 3 grams of fecal sample mixed with water was centrifuged for 5 minutes at $1200 \mathrm{rpm}$ (Eppendorf 5804, Germany). After pouring out the supernatant the sucrose flotation solution was added in the test tube. The sediment was than stirred and centrifuged again. After 5 minutes the test tube was refilled with flotation solution (until a meniscus formed) and covered with cover glass. After one hour of egg flotation the coverslip was removed and placed on the glass slide. For the detection of Giardia cysts the zinc sulphate flotation solution (specific gravity of 1.18) was used for each fecal sample. All samples were further examined under the light microscope at 20x and 40x magnification (Leica Microsystems, DM 5000B light microscope, Germany).

\section{Parasitological examination of soil samples}

In order to identify the presence of parasitic germs in the environment totally 65 soil samples were collected within the vicinity of human settlements and around the kennels and dog pens. 32 samples were from village $A$ and 33 from village $B$. The sand samples were surveyed according to the Kazacos (1983). Briefly, $100 \mathrm{~g}$ of pooled sand sample, $100 \mathrm{ml}$ of water and $0.5 \mathrm{ml}$ of Tween 40 were mixed and decanted for 10 minutes. Subsequently the samples were sieved and replenished with $1000 \mathrm{ml}$ of water. After one hour sedimentation the soil samples were centrifuged (Eppendorf 5804, Germany) and then floated with sucrose flotation solution (specific gravity of 1.3). Samples were examined under the light microscope at 20x and 40x magnification (Leica Microsystems, DM 5000B light microscope, Germany). 

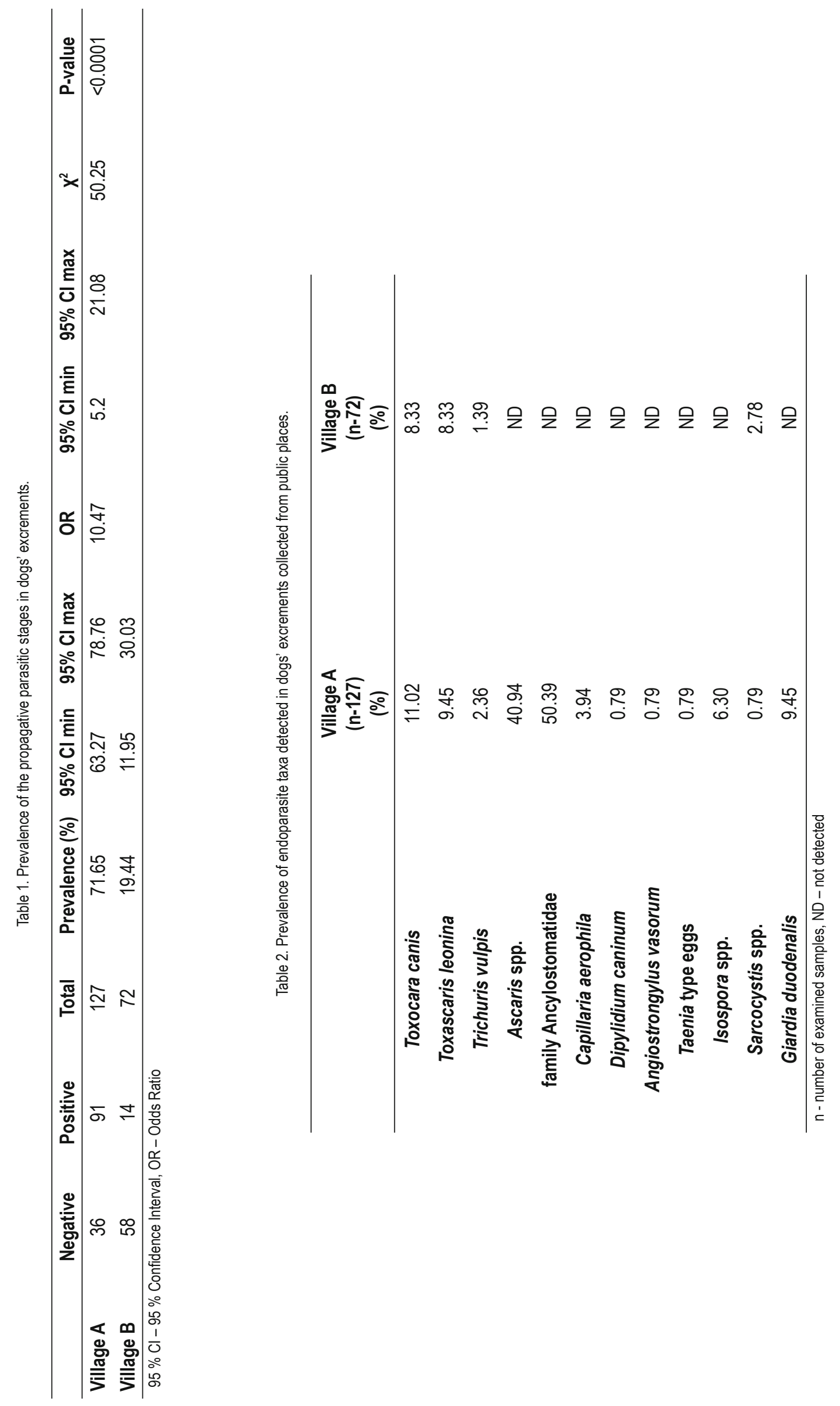

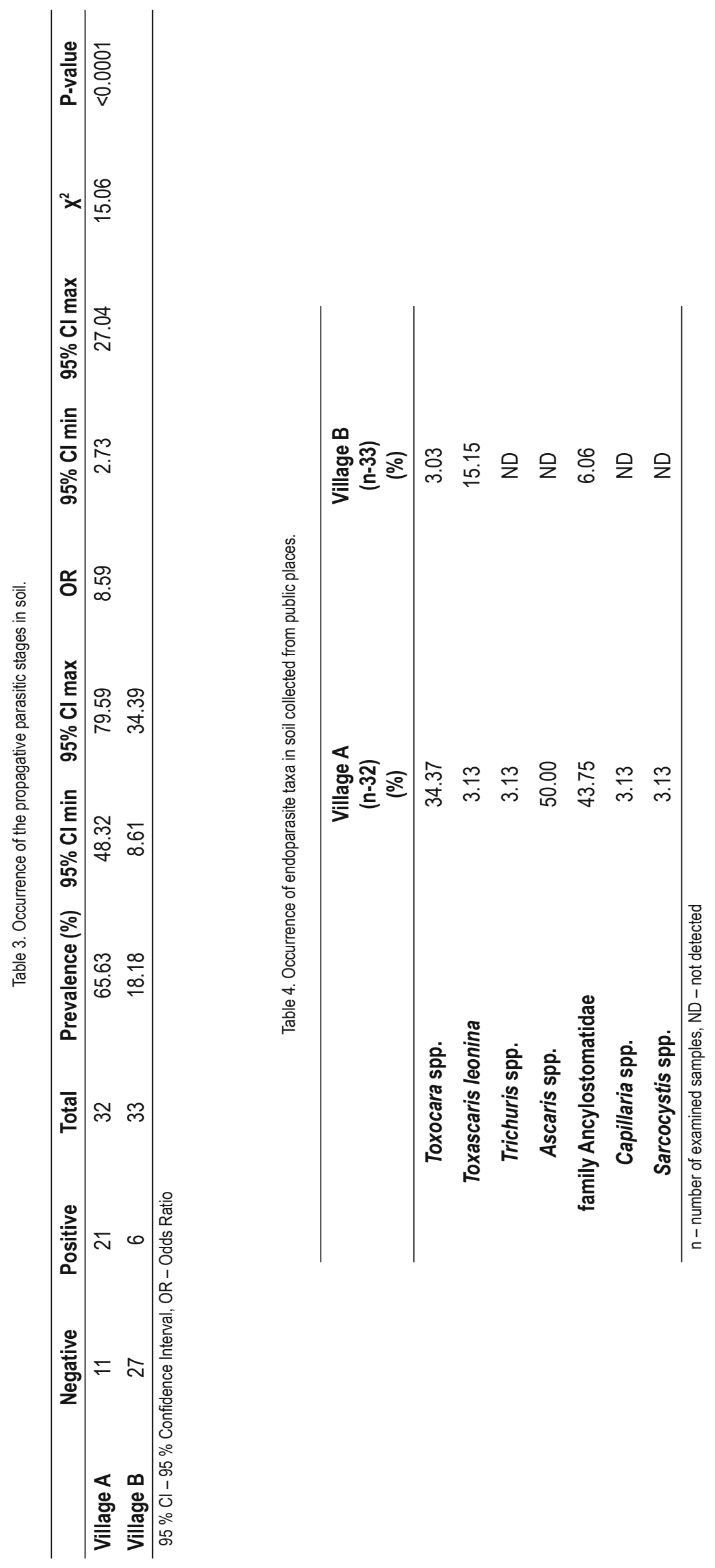

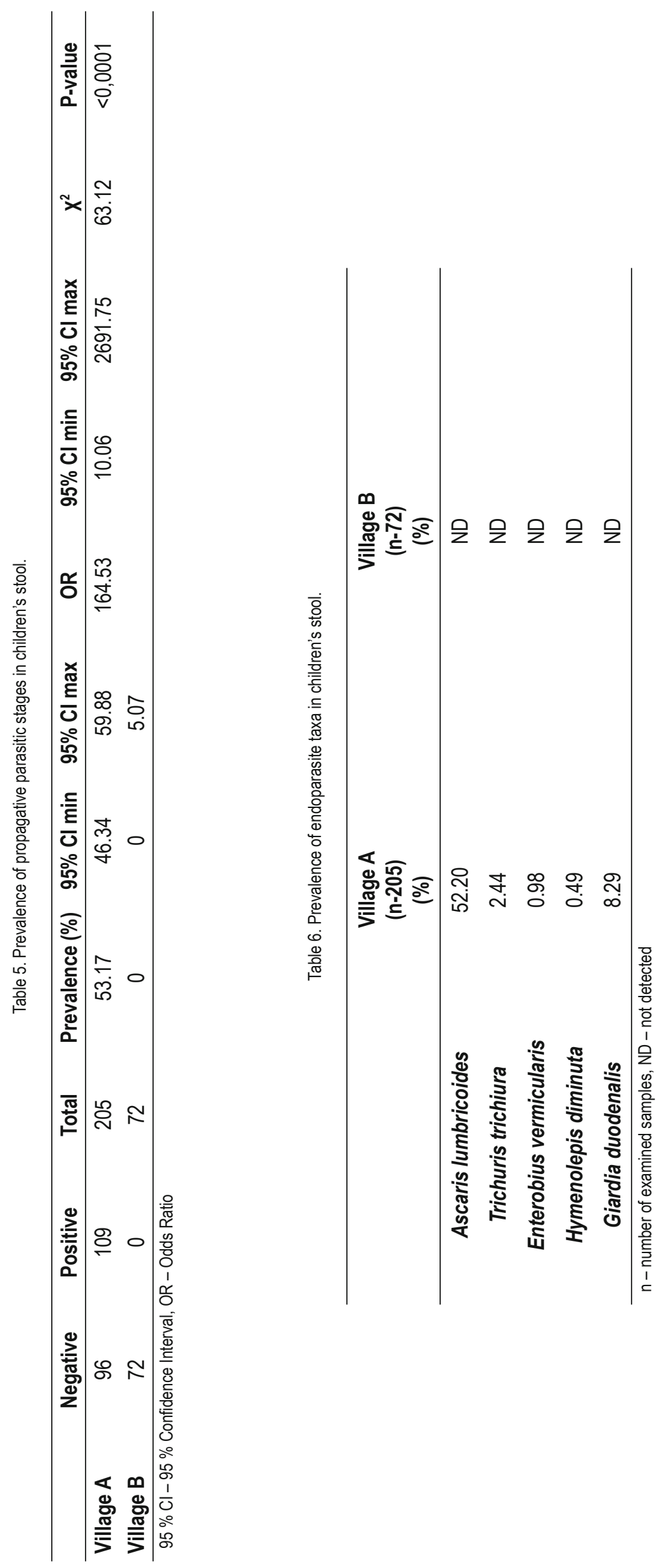


\section{Parasitological examination of stool samples}

Totally, 277 children's stool samples were collected into the plastic containers. After an informed consent was signed by parents or legal guardians stool containers with unique identifiers were handed out together with the instruction how to return them. Containers with stool samples (up to $15 \mathrm{~g}$ of morning stool) were stored in refrigerator without any conservation at $4{ }^{\circ} \mathrm{C}$ and transferred to the laboratory at the Institute of Parasitology SAS for the examination which was performed within $24-48$ h. Samples were examined with commercially available kit (Paraprep L, Mondial, France). Briefly, for each stool sample $2 \mathrm{ml}$ of ethyl acetate solution and $0.5 \mathrm{~g}$ of stool sample was added to $6 \mathrm{ml}$ of $10 \%$ formalin in a mixing chamber. The chamber was than connected through filter with a conical collection chamber. Mixed content was incubated for $24 \mathrm{~h}$ at room temperature and the tube was centrifuged at 1000 rpm for 1 minute (Eppendorf 5804, Germany). The entire samples volumes were collected into the collection chambers. The supernatant was discarded and the sediment placed on microscope slides and covered with coverslip. The entire area was examined at 20x and 40x magnification with Leica DM 5000B light microscope (Leica Microsystems, Germany).

\section{Statistical methods}

Statistical analysis was performed using Vassar Stats (www.vassarstats.net). $95 \%$ confidence intervals (95\% Cls) and Odds ratio (OR) with $95 \%$ confidence intervals (95\% Cls) were determined. To compare the potential risk factors a Chi-square test $\left(X^{2}\right.$; if all expected cell values were equal to or greater than 5) or a Fisher's exact test (if any expected cell value was less than 5) were used.

\section{Results}

Out of 199 examined dogs' fecal samples $52.76 \%$ of them contained parasitic germs. Intestinal parasites infections were detected in both examined villages. There were considerable differences in the prevalence and species diversity of detected helminths between village $A$ and $B$. Meanwhile the prevalence among dogs from the village A was $71.65 \%$ (95\% Cl: 63.27 - $78.76 \%$ ) the prevalence of infection among dogs from the village $B$ was only $19.44 \%$ (95 \% Cl: $11.95-30.03 \%$ ). This difference was highly significant $\left(X^{2}=50.25, P<0.0001\right)$ (Table 1). The odds for the infection were higher in dogs from the village $A$ than dogs from the village $B(O R=10.47,95 \% \mathrm{Cl}: 5.20-21.08)$.

In 127 examined samples from the village $A$ (low hygienic standards) 12 different taxa of parasites were detected. For the most part the eggs of Ancylostomatidae family (50.39\%), Ascaris spp. eggs (40.94\%) Toxocara canis eggs (11.02\%), eggs of Toxascaris leonina $(9.45 \%)$, Giardia duodenalis cysts $(9.45 \%)$, oocysts of Isospora spp. (6.30\%), Capillaria aerophila eggs (3.94\%), Trichuris vulpis eggs (2.36\%), Taenia type eggs (0.79\%), Dipylidium caninum eggs (0.79\%), Angiostrongylus vasorum larvae (0.79\%) and Sarcocystis spp. oocysts $(0.79 \%)$ were present. In village B (high hygienic standards) only 4 taxa of parasites in 72 dogs' excrements were found. To be exact the eggs of T. leonina, T.canis, T. vulpis and Sarcocystis spp. oocysts were detected (Table 2).

High prevalence of the endoparasitic developmental stages in dogs' feces present a risk factor for the soil contamination, and consequently to the population living in such locality. For this reason, we have examined the occurrence of helminth eggs in the soil. Out of 65 collected soil samples parasites were detected in 27 $(41.54 \%)$ of them. The soil samples from the village A were contaminated more than samples from village $B$. In village A $65.63 \%$ of soil samples contained parasites, while in village $B$ only $18.18 \%$ positivity was observed. This difference was highly significant $\left(X^{2}=\right.$ 15.06, $P<0.0001, \mathrm{OR}=8.59$; Table 3). In a village A, Ascaris spp. $(50.00 \%)$ and eggs from the family Ancylostomatidae (43.75\%) as well as the Toxocara spp. (34.37\%) were the most frequent. As shown on Table 4, the eggs of T. leonina, Trichuris spp., Capillaria spp. and oocysts of Sarcocystis spp. occurred occasionally in examined soil samples. The most prevalent parasitic taxa in soil samples from village B were T. leonina, Toxocara spp. and eggs of the family Ancylostomatidae (Table 4).

Overall, 277 fecal samples of children from village A (205 children) and village $B$ (72 children) were examined for the presence of parasites. The overall infection prevalence in children living in village A was $39.35 \%(109 / 277)$. No children from the village B were found to be positive for the presence of parasites. In contrast the prevalence of propagative parasitic stages among children from the village $A$ was $53.17 \%$. This difference was highly significant $\left(X^{2}=63.12, P<0.0001\right)$ and Roma children had higher odds to become infected by parasites than children living in village $B$ (OR $=164.53$, Table 5). Despite living in the close proximity both groups children (Roma and non-Roma) still maintain their specific life style what include different hygiene standards and live with pets. The explanation is obvious. Risk factors in urban settings were not disrupted and both groups of children remained segregated. In children from the village $A$, the most prevalent parasite was A. lumbricoides. Ascarid eggs were found in $52.20 \%$ of the stool samples (107/205). The cysts of $G$. duodenalis were found in $8.29 \%$ samples (17/205) and eggs of $T$. trichiura in $2.44 \%(5 / 205$; Table 6). Hymenolepis diminuta (0.49\%) eggs were observed less often. However, the perianal swabs and adhesive cellophane-tape tests for the prevalence of Enterobius vermicularis were not performed. The eggs of $E$. vermicularis were found unintentionally in the stool (Table 6).

The gastrointestinal parasites infestation in dogs and children persisted throughout the year (Tables 7-9). G. duodenalis infections in canine and children population in village $A$ were observed particularly during winter and spring (Table 7 and 9). In the village Alocation represented by lower hygienic standards, at least one soil sample from monthly collection contained parasitic germs. Most of helminth eggs have developed into larvae or reached various developmental stages. The egg counts per sample varied from 1 to 88 (per $100 \mathrm{~g}$ of dry soil). The egg counts were highest in the 
Table 7. The monthly occurrence of endoparasites in dogs' excrements collected from public places in village A.

\begin{tabular}{|c|c|c|c|c|c|c|c|c|c|c|c|c|}
\hline & $\begin{array}{c}\text { XI. } \\
(n-16) \\
(p)\end{array}$ & $\begin{array}{c}\text { XII. } \\
(n-15) \\
(p)\end{array}$ & $\begin{array}{c}\text { I. } \\
(\mathrm{n}-8) \\
(p)\end{array}$ & $\begin{array}{c}\text { II. } \\
(n-6) \\
(p)\end{array}$ & $\begin{array}{c}\text { III. } \\
(n-12) \\
\text { (p) }\end{array}$ & $\begin{array}{c}\text { IV. } \\
(n-13) \\
\text { (p) }\end{array}$ & $\begin{array}{c}\text { V. } \\
(n-13) \\
(p)\end{array}$ & $\begin{array}{c}\text { VI. } \\
(n-7) \\
(p)\end{array}$ & $\begin{array}{l}\text { VII. } \\
(n-8) \\
(p)\end{array}$ & $\begin{array}{l}\text { VIII. } \\
(n-8) \\
(p)\end{array}$ & $\begin{array}{c}\text { IX. } \\
(n-8) \\
(p)\end{array}$ & $\begin{array}{c}X . \\
(n-13) \\
(p)\end{array}$ \\
\hline Toxocara canis & 1 & 3 & 4 & 0 & 0 & 1 & 2 & 0 & 0 & 0 & 1 & 2 \\
\hline Toxascaris leonina & 0 & 3 & 1 & 0 & 0 & 3 & 2 & 0 & 1 & 0 & 0 & 2 \\
\hline Trichuris vulpis & 0 & 0 & 2 & 0 & 0 & 0 & 0 & 0 & 1 & 0 & 0 & 0 \\
\hline Ascaris spp. & 6 & 7 & 5 & 1 & 6 & 9 & 6 & 1 & 1 & 5 & 4 & 1 \\
\hline family Ancylostomatidae & 9 & 10 & 4 & 3 & 10 & 6 & 5 & 3 & 3 & 3 & 5 & 3 \\
\hline Capillaria aerophila & 0 & 0 & 0 & 0 & 0 & 1 & 0 & 2 & 0 & 1 & 1 & 0 \\
\hline Dipylidium caninum & 0 & 0 & 0 & 0 & 1 & 0 & 0 & 0 & 0 & 0 & 0 & 0 \\
\hline Angiostrongylus vasorum & 0 & 0 & 0 & 0 & 1 & 0 & 0 & 0 & 0 & 0 & 0 & 0 \\
\hline Taenia type eggs & 1 & 0 & 0 & 0 & 0 & 0 & 0 & 0 & 0 & 0 & 0 & 0 \\
\hline Isospora spp. & 0 & 3 & 1 & 0 & 1 & 0 & 1 & 2 & 0 & 0 & 0 & 0 \\
\hline Sarcocystis spp. & 0 & 0 & 0 & 0 & 0 & 0 & 0 & 1 & 0 & 0 & 0 & 0 \\
\hline Giardia duodenalis & 1 & 4 & 0 & 0 & 3 & 0 & 4 & 0 & 0 & 0 & 0 & 0 \\
\hline
\end{tabular}

$n$ - number of examined samples, $p$ - number of positive samples

Table 8. The monthly occurrence of endoparasites in dogs' excrements collected from public places in village B.

\begin{tabular}{|c|c|c|c|c|c|c|c|c|c|c|c|c|}
\hline & $\begin{array}{c}X I . \\
(n-6) \\
(p)\end{array}$ & $\begin{array}{l}\text { XII. } \\
(n-6) \\
(p)\end{array}$ & $\begin{array}{c}\text { I. } \\
(n-3) \\
(p)\end{array}$ & $\begin{array}{c}\text { II. } \\
\text { (n-11) } \\
\text { (p) }\end{array}$ & $\begin{array}{c}\text { III. } \\
\text { (n-10) } \\
\text { (p) }\end{array}$ & $\begin{array}{l}\text { IV. } \\
(n-6) \\
(p)\end{array}$ & $\begin{array}{c}V . \\
(n-5) \\
(p)\end{array}$ & $\begin{array}{l}\text { VI. } \\
(n-6) \\
(p)\end{array}$ & $\begin{array}{l}\text { VII. } \\
(n-6) \\
(p)\end{array}$ & $\begin{array}{l}\text { VIII. } \\
(n-6) \\
(p)\end{array}$ & $\begin{array}{c}\text { IX. } \\
(n-4) \\
(p)\end{array}$ & $\begin{array}{c}X . \\
(n-3) \\
(p)\end{array}$ \\
\hline Toxocara canis & 2 & 2 & 0 & 1 & 0 & 0 & 0 & 0 & 0 & 1 & 0 & 0 \\
\hline Toxascaris leonina & 0 & 0 & 1 & 0 & 1 & 0 & 0 & 0 & 0 & 0 & 3 & 2 \\
\hline Trichuris vulpis & 0 & 0 & 1 & 0 & 0 & 0 & 0 & 0 & 0 & 0 & 0 & 0 \\
\hline Ascaris spp. & ND & ND & ND & ND & ND & ND & ND & ND & ND & ND & ND & ND \\
\hline family Ancylostomatidae & ND & ND & ND & ND & ND & ND & ND & ND & ND & ND & ND & $\mathrm{ND}$ \\
\hline Capillaria aerophila & ND & ND & ND & ND & ND & ND & ND & ND & ND & ND & ND & $\mathrm{ND}$ \\
\hline Dipylidium caninum & ND & ND & ND & ND & ND & ND & ND & ND & ND & ND & ND & $\mathrm{ND}$ \\
\hline Angiostrongylus vasorum & ND & ND & ND & ND & ND & ND & ND & ND & ND & ND & ND & $\mathrm{ND}$ \\
\hline Taenia type eggs & ND & ND & ND & ND & ND & ND & ND & ND & ND & ND & ND & $\mathrm{ND}$ \\
\hline Isospora spp. & ND & ND & ND & ND & ND & ND & ND & ND & ND & ND & ND & $\mathrm{ND}$ \\
\hline Sarcocystis spp. & 0 & 0 & 0 & 0 & 0 & 0 & 0 & 1 & 0 & 0 & 1 & 0 \\
\hline Giardia duodenalis & ND & ND & ND & ND & ND & ND & ND & ND & ND & ND & ND & ND \\
\hline
\end{tabular}


centre of village and the number of eggs was reduced by distance. The most widespread were Ascaris spp. eggs which were detected in 16 soil samples. The eggs from family Ancylostomatidae (14 samples) and Toxocara spp. eggs (11 samples) were also found quite regularly. In opposite, quite rare was the occurrence of $T$. leonina, Trichuris spp. and Capillaria spp. (Table 10). In contrast, the soil samples from the village $B$ the developmental parasitic stages were detected in samples collected in January, March, April and September. Only three taxa were identified: T. leonina (5 samples), eggs from the family Ancylostomatidae (2 samples) and Toxocara spp. (1 sample; Table 11).

\section{Discussion}

In 27 countries representing the EU it is estimated that $16 \%$ of its citizens (about 80 million people) live below the poverty level. Poverty, defined as $60 \%$ of particular country median income in Europe, is distributed fairly alongside well-defined quartiles. The gross domestic product (GDP) per capita organizes countries into 4 quartiles. Most of the countries in the top two quartiles are represented by western European nations. All the poorest and lowest GDP per capita countries are geographically located in southern and eastern part of the European region. (Hotez \& Gurwith, 2011). Intestinal helminth and protozoan infections occur not only among those living in the poverty but also in the more affluent part of Europe. In Slovakia, the population living in poverty is concentrated typically in segregated Roma settlements. Life in the shelters, on the outskirts of towns and villages, or in the forests vicinity expose the Roma people more to the wildlife and the other potential biological agents (mosquitoes, ticks, flies, etc.) thus allowing infections to spread. At the same time, on a small area, a large number of people live together with domestic animals that are often without a proper veterinary control. Moreover, within the vicinity of these settlements animals' excrements and human feces concentrate without an appropriate sanitary control what represents a significant risk for the circulation of soil transmitted infections of animals and man.

The occurrence of intestinal helminth and protozoan infections in children represent a health problem especially in the rural areas with low standard of hygiene (Rudohradská et al., 2012; Harhay et al., 2010; Al-Mekhlafi et al., 2016). Therefore, we determined and compared the occurrence of parasitic infections in dogs, children population and soil found in two neighbouring villages with different levels of hygiene and socio-economic conditions of the population.

Parasitic infections were present in both study areas, but in the village $B$ with a higher standard of living, better personal and communal hygiene levels and better dogs' care a lower occurrence of the parasitic infections in dogs and less contaminated soil were recorded. The total prevalence of intestinal parasites among dogs from the village A with predominance of Roma minority was $71.65 \%$ and 12 different taxa with predominance of family Ancylostomatidae and Ascaris spp. were identified. The presence of Ascaris spp. provides evidence dogs coprophagous habits of dogs. Ascariasis spreads primarily by fecal contamination of the environment around human dwellings because of defecation outside the toilets. Such behaviour is called promiscuity defecation (Traub et al., 2002). Such high prevalence numbers bear a resemblance with the situation in developing countries in Asia, Africa or South Amerika. Traub et al. (2002) found that $94 \%$ of dogs living in poor communities in India eliminate the eggs from the family Ancylostomatidae and $31 \%$ dogs pass the eggs of Ascaris spp. In a resource-limited urban community in Gauteng, South Africa, $88 \%$ of dogs have been infected by Ancylostoma caninum and $36 \%$ were harbouring T. canis (Minnaar \& Krecek, 2001). Rubel et al. (2003) showed that the higher toxacariasis infection rate was associated with lower financial income. Also hookworm and whipworm infections occur more often in economically deprived localities (Rubel \& Wisnivesky, 2005).

The mean prevalence of intestinal parasites in dogs from village with better hygiene was $19.44 \%$ and only 4 taxa were detected. $T$. leonina and $T$. canis appeared to be most frequent. This was followed by Sarcocystis spp. and T. vulpis. Regarding the dogs fecal samples, $T$. leonina was the most often detected species in the soil samples from village with better environmental hygiene. Previous studies from Slovak Republic show that $45.1 \%$ of dogs were infected by intestinal parasite, especially by T. canis (21.9\%), hookworms (18.4\%), whipworms (10.0\%) or T. leonina $(7.3 \%) ;$ (Szabová et al., 2007). Our results are comparable to the records from neighbouring countries. Helminth prevalence among dogs in Poland was $34.2 \%$ in rural locations and 56.5 $80.9 \%$ in dog shelters. The eggs of the nematodes from family Ancylostomatidae were the most frequent, followed by T. vulpis and $T$ canis. $T$. leonina was present among dogs in shelters, but was missing among rural dogs (Borecka, 2004). Very similar infection rates were found among dogs from the rural areas in the Czech Republic, where $41.7 \%$ of dogs harboured some species of intestinal parasites. However the most prevalent was T. canis and the eggs from family Ancylostomatidae were detected only sporadically (Dubná et al., 2007).

The occurrence of $G$. doudenalis in dogs from the village A with low hygienic standard has also been recorded. Study of Marangi et al. (2008) evaluated the presence of giardiasis in dogs and children living in a disadvantaged and socially deprived small Roma community found that $5 / 14$ (35\%) children were found positive by microscopic examination. Additionally 8/14 (57\%) dogs tested both, microscopically and by molecular methods were positive for $G$. duodenalis. In the territory of Eastern Slovakia the giardia infections frequency was examined by Szabová et al. (2007). The overall prevalence of the Giardia cysts in dogs' excrements from shelters in the cities Trebišov, Košice and Zvolen was 1.6 \%. Similarly, Goldová et al. (2011) found that the giardiasis prevalence in dogs less than 7 months old was $69.1 \%$. Meanwhile in older animals the prevalence dropped to $36.9 \%$. The activities associated with the maintenance and landscaping of urban green spaces may 
Table 9. The monthly occurrence of endoparasites in children from the village A.

\begin{tabular}{|c|c|c|c|c|c|c|c|c|c|c|c|c|}
\hline & $\begin{array}{c}\text { XI. } \\
(n-18) \\
(p)\end{array}$ & $\begin{array}{c}\text { XII. } \\
\text { (n-20) } \\
\text { (p) }\end{array}$ & $\begin{array}{c}\text { I. } \\
\text { (n-15) } \\
\text { (p) }\end{array}$ & $\begin{array}{c}\text { II. } \\
(n-10) \\
(p)\end{array}$ & $\begin{array}{c}\text { III. } \\
\text { (n-18) } \\
\text { (p) }\end{array}$ & $\begin{array}{c}\text { IV. } \\
\text { (n-20) } \\
\text { (p) }\end{array}$ & $\begin{array}{c}\text { V. } \\
(n-27) \\
(p)\end{array}$ & $\begin{array}{c}\text { VI. } \\
\text { (n-16) } \\
\text { (p) }\end{array}$ & $\begin{array}{c}\text { VII. } \\
(n-20) \\
(p)\end{array}$ & $\begin{array}{l}\text { VIII. } \\
\text { (n-10) } \\
(p)\end{array}$ & $\begin{array}{c}\text { IX. } \\
(n-11) \\
(p)\end{array}$ & $\begin{array}{c}X . \\
(n-20) \\
(p)\end{array}$ \\
\hline Ascaris lumbricoides & 7 & 10 & 9 & 9 & 11 & 7 & 25 & 6 & 0 & 1 & 5 & 17 \\
\hline Trichuris trichiura & 2 & 1 & 0 & 1 & 0 & 0 & 0 & 0 & 0 & 0 & 0 & 1 \\
\hline Enterobius vermicularis & 0 & 0 & 0 & 0 & 1 & 0 & 0 & 0 & 0 & 0 & 0 & 1 \\
\hline Hymenolepis diminuta & 0 & 0 & 0 & 1 & 0 & 0 & 0 & 0 & 0 & 0 & 0 & 0 \\
\hline Giardia duodenalis & 1 & 0 & 0 & 0 & 0 & 0 & 16 & 0 & 0 & 0 & 0 & 0 \\
\hline
\end{tabular}

$\mathrm{n}$ - number of examined samples, $\mathrm{p}$ - number of positive samples

Table 10. The monthly occurrence of endoparasites in soil from the village A.

\begin{tabular}{|c|c|c|c|c|c|c|c|c|c|c|c|c|}
\hline & $\begin{array}{c}\text { XI. } \\
(n-3) \\
(p)\end{array}$ & $\begin{array}{l}\text { XII. } \\
(n-3) \\
(p)\end{array}$ & $\begin{array}{c}\text { I. } \\
(n-2) \\
(p)\end{array}$ & $\begin{array}{c}\text { II. } \\
(n-0) \\
(p)\end{array}$ & $\begin{array}{c}\text { III. } \\
(n-3) \\
(p)\end{array}$ & $\begin{array}{c}\text { IV. } \\
(n-3) \\
(p)\end{array}$ & $\begin{array}{c}V . \\
(n-3) \\
(p)\end{array}$ & $\begin{array}{c}\text { VI. } \\
(n-3) \\
(p)\end{array}$ & $\begin{array}{l}\text { VII. } \\
(n-3) \\
(p)\end{array}$ & $\begin{array}{l}\text { VIII. } \\
(n-3) \\
(p)\end{array}$ & $\begin{array}{c}\text { IX. } \\
(n-3) \\
(p)\end{array}$ & $\begin{array}{c}X . \\
(n-3) \\
(p)\end{array}$ \\
\hline Toxocara spp. & 0 & 1 & 2 & - & 2 & 1 & 0 & 1 & 1 & 1 & 1 & 1 \\
\hline Toxascaris leonina & 0 & 0 & 0 & - & 1 & 0 & 0 & 0 & 0 & 0 & 0 & 0 \\
\hline Trichuris spp. & 0 & 0 & 0 & - & 1 & 0 & 0 & 0 & 0 & 0 & 0 & 0 \\
\hline Ascaris spp. & 1 & 1 & 2 & - & 2 & 2 & 0 & 1 & 3 & 2 & 1 & 1 \\
\hline family Ancylostomatidae & 2 & 2 & 2 & - & 1 & 1 & 1 & 0 & 1 & 0 & 2 & 2 \\
\hline Capillaria aerophila & 0 & 0 & 0 & - & 1 & 0 & 0 & 0 & 0 & 0 & 0 & 0 \\
\hline Sarcocystis spp. & 0 & 0 & 0 & - & 1 & 0 & 0 & 0 & 0 & 0 & 0 & 0 \\
\hline
\end{tabular}

$n$ - number of examined samples, $p$ - number of positive samples

Table 11. The monthly occurrence of endoparasites in soil from the village B.

\begin{tabular}{|c|c|c|c|c|c|c|c|c|c|c|c|c|}
\hline & $\begin{array}{c}X I . \\
(n-3) \\
(p)\end{array}$ & $\begin{array}{c}\text { XII. } \\
(n-3) \\
(p)\end{array}$ & $\begin{array}{c}\text { I. } \\
\text { (n-3) } \\
\text { (p) }\end{array}$ & $\begin{array}{c}\text { II. } \\
(n-0) \\
(p)\end{array}$ & $\begin{array}{c}\text { III. } \\
\text { (n-3) } \\
\text { (p) }\end{array}$ & $\begin{array}{l}\text { IV. } \\
(n-3) \\
(p)\end{array}$ & $\begin{array}{c}V . \\
(n-3) \\
(p)\end{array}$ & $\begin{array}{l}\text { Vl. } \\
\text { (n-3) } \\
\text { (p) }\end{array}$ & $\begin{array}{l}\text { VIl. } \\
(n-3) \\
(p)\end{array}$ & $\begin{array}{l}\text { VIII. } \\
(n-3) \\
(p)\end{array}$ & $\begin{array}{c}\text { IX. } \\
(n-3) \\
(p)\end{array}$ & $\begin{array}{c}X . \\
(n-3) \\
(p)\end{array}$ \\
\hline Toxocara spp. & 0 & 0 & 0 & - & 1 & 0 & 0 & 0 & 0 & 0 & 0 & 0 \\
\hline Toxascaris leonina & 0 & 0 & 1 & - & 2 & 1 & 0 & 0 & 0 & 0 & 1 & 0 \\
\hline Trichuris spp. & ND & ND & ND & - & ND & ND & ND & ND & ND & ND & ND & ND \\
\hline Ascaris spp. & ND & ND & ND & - & ND & ND & ND & ND & ND & ND & ND & ND \\
\hline family Ancylostomatidae & 0 & 0 & 1 & - & 1 & 0 & 0 & 0 & 0 & 0 & 0 & 0 \\
\hline Capillaria aerophila & ND & ND & ND & - & ND & ND & ND & ND & ND & ND & ND & $\mathrm{ND}$ \\
\hline Sarcocystis spp. & ND & ND & ND & - & ND & ND & ND & ND & ND & ND & ND & ND \\
\hline
\end{tabular}


also contribute to the dispersion of dogs' and cats' excrements on large areas. After the excrements break-down all parasitic propagative stages disperse in the soil. Such contaminated soil become a source of infections and reinfections for animals, and poses a significant risk to man as well. Gawor et al. (2008) studied the epidemiological link between the likelihood of reinfection with soil transmitted helminths and children diagnosed with toxocarosis. Examination of the soil from around the homes of infected children have confirmed that more of the Toxocara spp. eggs are being found in rural locations than in samples collected from the urban environment. In contrast Antolova et al. (2015) studied seroprevalence of human Toxocara infections. Cross-sectional study confirmed the $22.1 \%$ seropositivity to Toxocara in 429 examined Roma inhabitants living in segregated settlements. Meanwhile only 4 of 394 samples from the non-Roma population were found to be positive.

Soil contamination by endoparasites developmental stages in areas inhabited with marginalized groups has been monitored by Rudohradská et al. (2011). The settlements environment where children lived and played was contaminated extensively with the parasite propagative stages, where up to $81.6 \%$ of examined soil samples were contaminated with helminths eggs (Ascaris spp., Toxocara spp., Trichuris spp. and strongyloid eggs). Occasionally the eggs of $T$. leonina and Spirocerca lupi were detected. The highest soil contamination was detected in villages Jarovnice, Zemplínska Teplica and Sečovce. Research of Štrkolcová et. al (2017) in segregated settlement Medzev (Eastern Slovakia) showed that Strongyloides stercoralis infections in children and dogs are frequent. Despite similar level of specific antibodies against $S$. stercoralis in all examined dogs Roma children showed higher seroprevalence (33.3 \%) when compared with non-Roma children (23.8 \%).

However, this study did not investigate the occurrence of cryptosporidiosis - a parasitic disease considered to be a widespread zoonosis. Its occurrence in Roma children was studied by Hasajová et. al (2014). Examination of 53 Roma and 53 non-Roma fecal samples led to the conclusion that the risk of Cryptosporidium infection is 12 times higher in the Roma children when compared to the non-Roma children. Moreover the occurrence of microsporidia as emerging pathogens in Slovak Roma children and their impact on public health was confirmed (Halánová et al., 2013).

Our results show that the high endoparasitic occurrence in the environment poses a significant risk to the human health. Most exposed are children of preschool age who play in public places what may result in the ingestion of contaminated soil. It should be stated that for example eggs of soil-transmitted helminths in feces need some time to embryonate and become infective because they are not immediately infective (Knop et al., 2012; Grimes et al., 2016). We have detected intestinal parasitic infections in $53.17 \%$ of examined Roma children. The predominant infections found were A. lumbricoides and G. duodenalis origin. Similarly, Rudohradská et al. (2012) studied the occurrence of selected intestinal endoparasites in 81 children living in eastern Slovakia in areas char- acterized by low hygienic and socioeconomic status. $56.8 \%$ of children were positive for the presence of intestinal parasites. $A$. lumbricoides was found to be the most prominent intestinal parasite $(24.7 \%)$. This was followed by T. trichiura (17.3\%) and Taenia type eggs (4.9\%). Cryptosporidium spp. (44.4\%) and G. duodenalis $(24.7 \%)$ were also detected in a quite high prevalence.

Due to the dogs free movement the soil around houses was highly contaminated with helminths eggs and protozoan cysts and served as a source of the infection spread. Thus, in addition to its own parasite fauna, human intestinal parasites are often passaged through the dogs' digestive system. Triggered by limited availability of sanitary facilities and the absence of sewage system in the village children also participated in soil contamination as well. One of the efficient ways for the reduction of parasitic infections is establishment of a reliable veterinary care. Regular dogs deworming, especially by the owners with small children, reduces the possibility of parasites spread. Introduction of a proper environmental hygiene measures, education in a basic hygiene habits and regular removal of dog excrements will prevent dispersion of parasite developmental stages into the environment. The results of this study were submitted to the local health and social services to utilise data further. Based on our results the preventive measures will be implemented through local community centres and physicians.

\section{Acknowledgement}

This work was supported by the scientific Grant Agency of the Ministry of Education of the Slovak Republic, by support from the Slovak Academy of Sciences, VEGA no. 2/0125/17 (0.6). The publication has been realised within the scope of the projects performed in the Centre of Excellence for Parasitology (Code ITMS: 26220120022) based on funding support from the Operational Programme "Research \& Development", which is funded by the European Regional Development Fund (0.4).

\section{References}

Adeoye, G.O., Osayemi, C.O., Oteniya, O., Onyemekeihia, S.O. (2007): Epidemiological Studies of Intestinal Helminthes and Malaria among Children in Lagos, Nigeria. Pak. J. Biol. Sci., 10: 2208 - 2212. DOI: 10.3923/pjbs.2007.2208.2212

Al-Mekhlafi, A.M., Abdul-Ghani, R., Al-Eryani, S. M., Saif-Ali, R., MAHDY, M.A.K. (2016): School-based prevalence of intestinal parasitic infections and associated risk factors in rural communities of Sana'a, Yemen. Acta Trop., 163: 135 - 141. DOI: 10.1016/j. actatropica.2016.08.009

Antolová D, JaRČušKa $P$, JaničKo $M$, Madarasová-Gecková $A$, Halánová M, Čisláková L, Kalinová Z, Reiterová K, Škutová M, Pella D, Mareková M., HepaMeta Team (2015): Seroprevalence of human Toxocara infections in the Roma and non-Roma populations of Eastern Slovakia: a cross-sectional study. Epidemiol. Infect., 143(10): 2249-58. DOI: 10.1017/S0950268814003665 
Bajer, A. (2008): Cryptosporidium and Giardia spp. infections in humans, animals and the environment in Poland. Parasitol. Res., 104(1): 1 - 17. DOI: 10.1007/s00436-008-1179-x

BoRECKA, A. (2004): Differentiation of Toxocara spp. eggs isolated from the soil by PCR-linked RFLP. Helminthologia, 41(4): 185- 187 Despommier, D. (2003): Toxocariasis: Clinical aspects, epidemiology, medical ecology, and molecular aspects. Clin. Microbiol. Rev., 16: 265 - 272, DOI: 10.1128/CMR.16.2.265-272.2003

DuBAYová, M. (2001): Rómovia v procesoch kultúrnej zmeny [Roma people in the process of cultural change]. Prešov: Vyd. Filozofická fakulta Prešovskej univerzity, 2001, 183 p. (In Slovak)

Dubná, S., Langrová, I., NÁpravíí, J., Jankovská, I., Vadlejch, J., PekÁr, S., Fechtner, J. (2007): The prevalence of intestinal parasites in dogs from Prague, rural areas, and shelters of the Czech Republic. Vet. Parasitol., 145(1-2): 120 - 128. DOI: 10.1016/j.vetpar.2006.11.006

Elyana, F. N., Al-Mekhlafi, H. M., Ithol, I., Abdulsalam, A. M., Dawaki, S., Nasr, N. A., Atroosh, W. M., Abd-Basher, M. H., Al-Areegl, M. A., Sady, H., Subramaniam, L. R., Anuar, T. S., Lau, Y. L., Moktar, N., SuRIN, J. (2016): A tale of two communities: intestinal polyparasitism among Orang Asli and Malay communities in rural Terengganu, Malaysia. Parasites \& Vectors, 9: 398. DOI 10.1186/s13071016-1678-z

Filadelfiová J, Gerbery D, Škobla D. (2007): Report on the living conditions of Roma in Slovakia. Bratislava: UNDP, Regional Bureau for Europe.

Gawor, J., Borecka, A., Żarnowska, H., MarczyŃska, M., Dobosz, S. (2008): Environmental and personal risk factors for toxocariasis in children with diagnosed disease in urban and rural areas of central Poland. Vet. Parasitol., 155(3-4): 217 - 222. DOI: 10.1016/j. vetpar.2008.05.016

Goldová, M., Valenčáková, A., Mojžlšová, J., Halanová, M., Letková, V., Ravaszová, P. (2011): Occurrence of Giardia and Cryptosporidium in dogs. In Southern European Veterinary Conference, 29 Sep - 2 Oct. 2011, Barcelona Spain

Grimes, J.E.T., Tadesse, G., Mekete, K., Wuletaw, Y., Gebretsadik, A., French, M.D., Harrison, W.E., Drake, L.J., Gardiner, I.A., Yard, E., Templeton, M.R.(2016): School water, sanitation, and hygiene, soil-transmitted helminths, and shistosomes: national mapping in Ethiopia. PLoS Negl. Trop. Dis., 10(3): e0004515. DOI:10.1371/ journal.pntd.0004515

Halánová M, ValenčákováA, Malčeková B, Kváč M, Sak B, KvĚtoñová D, BÁlENT P, ČISLÁKOVÁ L. (2013): Occurrence of microsporidia as emerging pathogens in Slovak Roma children and their impact on public health. Ann. Agric. Environ. Med., 20(4): 695 - 698.

Harhay, M. O., Horton, J., Olliaro, P.L. (2010): Epidemiology and control of human gastrointestinal parasites in children. Expert Rev. Anti. Infect. Ther., 8(2): 219 - 234. DOI: 10.1586/eri.09.119

Hasajová A, Valenčáková A, Malčeková B, Danišová O, Halán M, Goldová M, Sak B, KvĚtoñová D, Kváč M, Halánová M. (2014): Significantly higher occurrence of Cryptosporidium infection in Roma children compared with non-Roma children in Slovakia. Eur. J.
Clin. Microbiol. Infect. Dis., 33(8): 1401-6. DOI:10.1007/s10096014-2082-2

Hotez P. J., Alvarado M., Basáñez M. G., Bolliger, I., Bourne, R., Boussinesq, M., Brooker, S.J., Brown, A.S., Buckle, G., BudKe, C.M., Carabin, H., Coffeng, L.E., Fèvre, E.M., Fürst, T., Halasa, Y.A., Jasrasaria, R., Johns, N.E., Keiser, J., King, C.H., Lozano, R., Murdoch, M.E., O'Hanlon, S., Pion, S.D., Pullan, R.L., Ramaiah, K.D., Roberts, T., Shepard, D.S., Smith, J.L., Stolk, W.A., UndurRaga, E.A., Utzinger, J., Wang, M., Murray, C.J., Naghavi, M. (2014): The global burden of disease study 2010: Interpretation and implications for the neglected tropical diseases. PLoS Negl. Trop. Dis., 8(7): e2865. DOI:10.1371/journal.pntd.0002865

Hotez, P. J., GuRWith, M. (2011): Europe's neglected infections of poverty. Int. J. Inf. Dis., 15(9): e611 - e619. DOI:10.1016/j. ijid.2011.05.006

KazACOS, K. R. (1983): Improved method for recovering ascarid and other helminth eggs from soil associated with epizootics and during survey studies. Am. J. Vet. Res., 44: 896 - 900

Knopp, S., Steinmann, P., Keiser, J., Utzinger, J. (2012): Nematode infections: soil-transmitted helminths and Trichinella. Infect. Dis. Clin. North. Am., 26: 341-358. DOI: 10.1016/j.idc.2012.02.006

Madarasová Gecková, A., Babinská, I., Bobáková, D., Dankulincová Veselská, Z., Bosáková, L., Kolarčík, P., Jarčuška, P., Pella, D., HaLÁNOVÁ, M., HepaMeta TEAM (2014): Socioeconomic characteristics of the population living in Roma settlements and their association with health and health-related behaviour. Cent. Eur. J. Public. Health., Supplement 2014: S57 - S64. DOI: 10.21101/cejph.a3903 MACPHERSON, C.N.L. (2013): The epidemiology and public health importance of toxocariasis: A zoonosis of global importance. Int. J. Parasitol., 43: 999 - 1008. DOI: 10.1016/j.ijpara.2013.07.004

Marangl, M, Berrillil, F, Otranto, D, Giangaspero, A. (2010): Genotyping of Giardia duodenalis among children and dogs in a closed socially deprived community from Italy. Zoonoses Public Health, 57(7 - 8): e54 - 58. DOI: 10.1111/j.1863-2378.2009.01304.x MinnaAR, W.N., KRECEK, R.C. (2001): Helminths in dogs belonging to people in a resource-limited urban community in Gauteng, South Africa. Onderstepoort J. Vet. Res., 68(2): 111 - 117

Montresor, A., Crompton, D.W.T., Hall, A., Bundy, D.A., Savioli, L. (1998): Guidelines for the evaluation of soil-transmitted helminthiasis and schistosomiasis at a community level. World Health Organization, Geneva. WHO/CTD/SIP/98.1.

MušINKA, A. (2002): Bývanie Rómov [Housing of Roma people]. In VAŠEČKA, M. (Ed) Čačipen pal o Roma/Súhrnná správa o Rómoch [Comprehensive report of Roma people]. Bratislava (IVO).

Mušinka, A., Škobla, D., Hurrle, J., Matlovičová, K., Kling, J.. (2014): Atlas of Roma communities in Slovakia 2013. Regional centre for UN developmental programme for EU in Bratislava. Bratislava: UNDP, 2014

Ondriska, F., Mačuhová, K., Melicherová, J., Reiterová, K., Valentová, D., Beladičová, V., Halgoš, J. (2013): Toxocariasis in urban environment of western Slovakia. Helminthologia, 50(4): 261 - 268. DOI 10.2478/s11687-013-0139-x 
Papajová, I., PIPIKová, J., PapaJ, J., ČIŽmár, A. (2014): Parasitic contamination of urban and rural environments in the Slovak Republic: dog's excrements as a source. Helminthologia, 51(4): $273-280$. DOI: 10.2478/s11687-014-0241-8

Von Philipsborn, P., Steinbeis, F., Bender, M.E., Regmi, S., TinneMANN, P. (2015): Poverty-related and neglected diseases - an economic and epidemiological analysis of poverty relatedness and neglect in research and development. Glob. Health. Action, 8: 25818, DOI: 10.3402/gha.v8.25818

Pullan, R.L., Smith, J.L., Jasrasaria, R., Brooker, S.J. (2014): Global numbers of infection and disease burden of soil transmitted helminth infections in 2010. Parasit. Vectors, 7: 37. DOI: 10.1186/1756-3305-7-37

Røttingen, J.A., Regmi, S., Eide, M., Young, A.J., Viergever, R.F., Årdal, C., Guzman, J., Edwards, D., Matlin, S.A., Terry, R.F. (2013): Mapping of available health research and development data: what's there, what's missing, and what role is there for a global observatory? Lancet, 382: 1286 - 1307. DOI: 10.1016/ S0140-6736(13)61046-6

Zunino, G., Santllín, G., Wisnivesky, C. (2003). Epidemiology of Toxocara canis in the dog population from two areas of different socioeconomic status, Greater Buenos Aires, Argentina. Vet. Parasitol., 115(3): $275-286$.

Rudohradská, P., Papajová, I., JuRlš, P. (2011): Pets as a source of parasitic soil contamination in the settlements of marginalised groups of inhabitants. Folia Vet., 55(1): 33 - 35
Rudohradská, P., Halánová, M., Ravaszová, P., Goldová, M., Valenčáková, A., Halán, M., Papajová, I., Pohorencová, A., Valko, J., ČISLÁKOVÁ, L., JURIŠ, P. (2012): Prevalence of intestinal parasites in children from minority group with low hygienic standards in Slovakia. Helminthologia, 49(2): 63 - 66. DOI:10.2478/s11687-0120013-2

Szabová, E., Juriš, P., Miterpáková, M., Antolová, D., Papajová, I., ŠEFČíkovÁ, H. (2007): Prevalence of important zoonotic parasites in dog populations from the Slovak Republic. Helminthologia, 44(4): 170 - 176. DOI:10.2478/s11687-007-0027-3

ŠtrkolcovÁ, G., Goldová, M., BockovÁ, E., MoJžlšovÁ, J. (2017): The roundworm Strongyloides stercoralis in children, dogs, and soil inside and outside a segregated settlement in Eastern Slovakia: frequent but hardly detectable parasite. Parasitol. Res., 116(3): 891 - 900. DOI: 10.1007/s00436-016-5362-1

Traub, R.J., Robertson, I.D., Irwin, P., Mencke, N., Thompson, R.A. (2002): The role of dogs in transmission of gastrointestinal parasites in a remote tea-growing community in northeastern India. Am. J. Trop. Med. Hyg., 67(5):539 - 545

Traversa, D., di Regalbono, A. F., di Cesare, A., La Torre, F., Drake, J., Pietrobeli, M. (2014): Environmental contamination by canine geohelminths. Parasit. Vectors, 7: 67. DOI: 10.1186/1756-33057-67

VassarStats: Website for Statistical Computation. Retrieved from http://www.vassarstats.net

WHO (2012): Defining disease types I, II and III - background document provided by the WHO secretariat. Geneva: WHO 